\title{
In vitro antiacne and antidandruff activity of extracted stigmasterol from seed waste of safflower (Carthamus tinctorius L.)
}

\author{
Monika Choudhary, Vartika Verma \& Nidhi Srivastava* \\ Department of Bioscience and Biotechnology, Banasthali Vidyapith, Rajasthan 304 022, India
}

\section{Article history}

Received: 27 November 2019 Accepted: 28 December 2019 Published: 31 December 2019

\section{Publisher}

Horizon e-Publishing Group

\section{*Correspondence}

Nidhi Srivastava

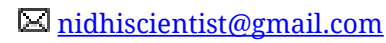

\begin{abstract}
The present study deals with the extraction of saponins and their characterization from the seed waste of safflower. The presence of stigmasterol in the extracted safflower seed waste (SSW) was confirmed by Thin Layer Chromatography (TLC), followed by Fourier-Transform Infrared Spectroscopy (FTIR) and High Performance Liquid Chromatography (HPLC) on the basis of its peak compared with stigmasterol standard. FTIR showed the identical functional groups of butanolic extract of SSW with standard while TLC and HPLC showed their notable peak and retention time with the same. Further in-vitro antiacne and antidandruff microbial activity of extracted stigmasterol was confirmed by disc diffusion method. This preliminary study has exhibited anti-acne and anti dandruff potential of Safflower seed waste extract, in future which could be used in therapies and cosmetic applications.
\end{abstract}

Keywords: Anti-acne; Anti-dandruff activity; Safflower seed waste; stigmasterol

Citation: Choudhary M, Verma V, Srivastava N. In vitro antiacne and antidandruff activity of extracted stigmasterol from seed waste of safflower (Carthamus tinctorius L.). Plant Science Today 2019;6(sp1):568-574. https://doi.org/10.14719/pst.2019.6.sp1.670

\begin{abstract}
Copyright: (c) Choudhary et. al. (2019). This is an open-access article distributed under the terms of the Creative Commons Attribution License, which permits unrestricted use, distribution, and reproduction in any medium, provided the original author and source are credited (https://creativecommons.org/licenses/by/4.0/).
\end{abstract}

Indexing: Plant Science Today is covered by Scopus, Web of Science, BIOSIS Previews, ESCI, CAS, AGRIS, UGC-CARE, CABI, Google Scholar, etc. Full list at http://www.plantsciencetoday.online 
Acacia auriculiformis against microbes has been explored. Saponin causes leakage of certain enzymes and proteins from the cell of microbes (5).

Microbes have the ability to cause various skin related diseases or inflammations including dandruff, infections around, nails, acne skin rashes. Phytochemicals with antimicrobial properties present in plant are of great importance in therapeutic treatment (6). There are reports on strong antimicrobial activity of saponins extract of Acacia species against different pathogenic organisms (7).

India has the largest producers of safflower followed by China, U.S.A etc. (8). Safflower is highly rich in PUFA (Poly unsaturated fatty acid) mainly linoleic acid, 76-80\% and carthamin (color dye). Commercial safflower seeds have thick and white hull while many experimental types seeds have thin, dark and stripped hull. White hulled varieties have $33-44 \%$ hull and 55-65\% kernel while $36-42 \%$ oil content and experimental thin hulled varieties have 55.5-44.5\% hull. Hull makes up a large part of seeds but have no reasonable value. Commercially hull contains large amount of fiber that lowers the market value of hulls and whole safflower meal. A byproduct (Seed meal) is a rich protein source of animal food but quality of the meal is very erratic due to various downstream processes. Safflower seed hull are unpalatable for the livestock feed and it constitutes only a small part of roughage. The seed meal contains phenolic glucosides which have cathartic activity and it can be removed through the extraction process (9). Isolated glucosides may further be used for their biological activities.

\section{Materials and Methods}

\subsection{Materials}

Safflower seed waste was collected from safflower oil industry, Lokhande, Latur, Maharashtra. Stigmasterol was purchased from Sigma-Aldrich, USA. HPLC grade water, acetonitrile and silica $20 * 20$ aluminum sheets purchased from Merck, India.

\subsection{Preparation of extract for phytochemical screening}

Safflower seed waste (SSW) was milled into powder by the grinder. Successive extraction of the sterol based compounds from the safflower seed waste was performed via solvents in a range of nonpolarpolar i.e. petroleum ether, chloroform, ethyl acetate and ethanol. The selected $50 \%$ aqueous methanol extract was air dried to get concentrated for further analysis of different class of compounds.

\subsection{Phytochemical analysis}

Phytochemical screening of aqueous methanolic extracts of SSW was conducted for alkaloids, flavonoids, steroids, terpenoids, tannins and saponins (Table 1) (10).
Table 1. List of phytochemicals analyzed in Safflower seed waste extract.

\begin{tabular}{cllc}
\hline S.No. Test & Method & Extract \\
\hline \multirow{2}{*}{1} & \multirow{2}{*}{ Alkaloids } & Alkaloids Mayer's test & + \\
& & Wagner's test & + \\
& & Dragendorff's test & - \\
\hline 2 & \multirow{2}{*}{ Terpenoids } & Liebermann-Burchard test & + \\
\hline \multirow{2}{*}{3} & \multirow{2}{*}{ Tannin } & Braymer's test & - \\
\hline 4 & Saponin & FeCl3 test & + \\
\hline \multirow{2}{*}{5} & \multirow{2}{*}{ Flavonoids } & Foam test & - \\
\hline \multirow{2}{*}{6} & Steroids & Lead acetate test & +++ \\
\hline \multirow{2}{*}{7} & \multirow{2}{*}{ Carbohydrates } & CHCl test & + \\
& & Benedict's test & + \\
\hline \multirow{2}{*}{8} & \multirow{2}{*}{ Protein } & Fehling's test & + \\
& & Ninhydrin test & + \\
\hline
\end{tabular}

\subsection{Extraction of sterol rich compounds}

$50 \%$ aqueous methanol extract of SSW was selected for the further analysis of saponins. Further extraction was done by two phase separation method i.e. water and ethyl acetate (11). Aqueous phase which was rich in saponins has been collected separately. Further partitioning was carried out butanol and diethyl ether. Finally, the butanolic phase was collected which was rich in compounds dependent on sterol (12).

\subsection{Silica gel column chromatography for purification of plant extracts}

Silica gel chromatography was used for separation of sterol rich butanolic (SRB). For separation of the extract, elution solvent ranging from of non polar to polar range was used. The eluted fractions have been accumulated over a certain period of time. Petroleum ether gradation and methanol have been used to elute the compounds.

\subsection{Characterization of sterol compounds}

Characterization of the SRB extract was done by thin layer chromatography (TLC), Fourier Transform Infra-red Spectroscopy (FTIR) and High performance liquid chromatography (HPLC). SRB extract spot was marked over silica sheets along with standard (stigmasterol). The mobile phase ratio was chloroform and methanol $(6: 1 \mathrm{v} / \mathrm{v})$ to develop the TLC plates. For spot visualization, vanillin sulphuric acid was sprayed on the plates followed by heating in oven for $100^{\circ} \mathrm{C}$.

For identification of various functional groups present in the SRB extract FTIR (Bruker Alpha-T spectrometer) analysis was performed (13). In FTIR spectra, few drops of extract were placed over instrument glass through which the laser passes. Spectra were obtained ion range from 400 to $4000 \mathrm{~cm}^{-1}$ and their functional groups were identified in accordance with characteristic peaks (14).

HPLC (Shimadzu LC-10A (Japan)) was carried out to separate and identify the 


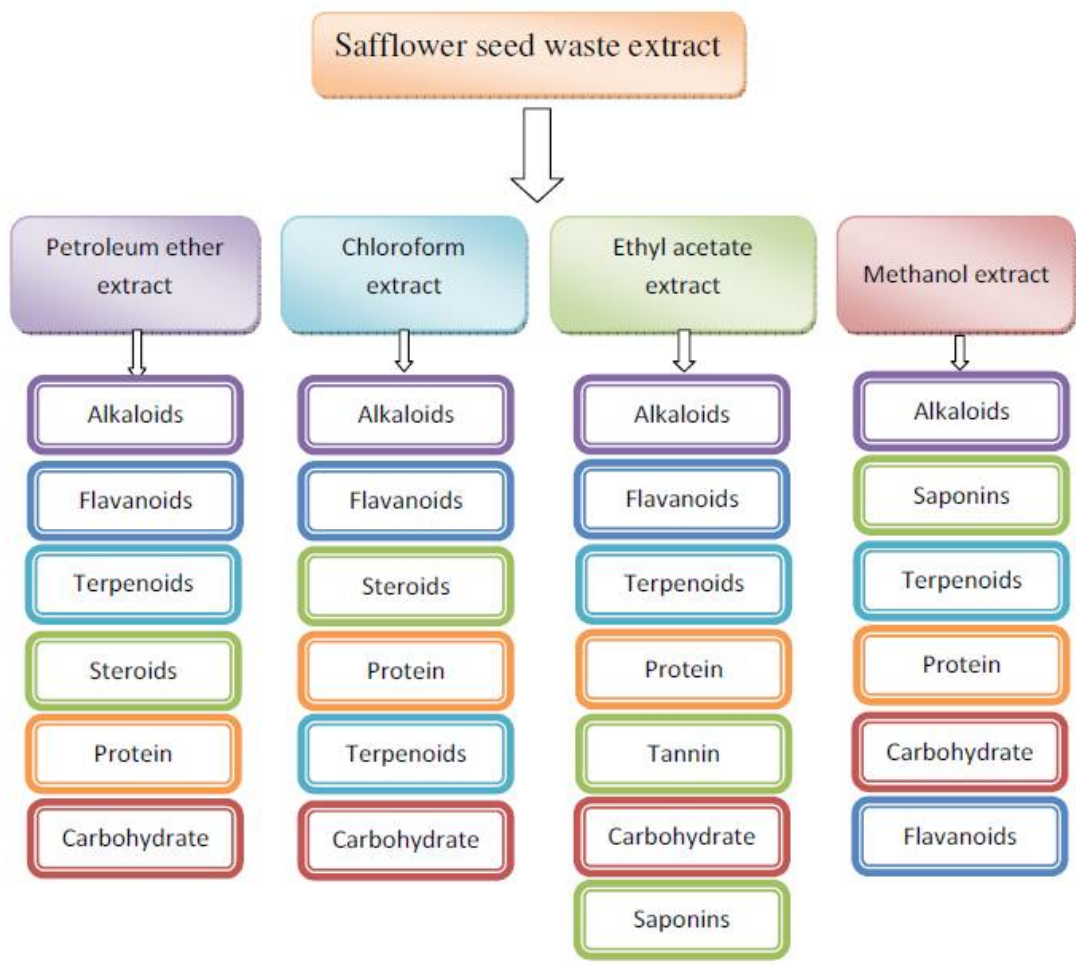

Fig. 1. Phytochemical analysis of different solvent extract of Safflower seed waste.

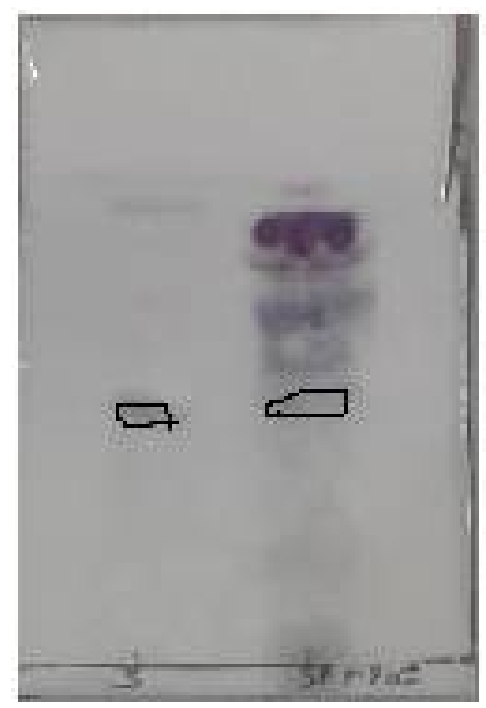

Fig. 2. TLC fingerprinting profile of Standard Stigma sterol (S) and SRB extract (Sample). compounds in the SRB extract. $20 \mu \mathrm{L}$ extract was injected, separated by C-18 Whattman ODS 5 column and detected at $254 \mathrm{~nm}$ wavelength. Acetonitrile and water were used as mobile phase with a constant flow rate of $1 \mathrm{ml} \mathrm{min}^{-1}(15)$.

\subsection{In vitro anti-bacterial activity of sterol rich butanolic extract}

The antimicrobial efficiency of the SRB extract was performed (16). 50 $\mu$ l of SRB extract was loaded on sterile disc and these discs were placed over already inoculated nutrient plates with acne causing bacteria. These plates were incubated at $37^{\circ} \mathrm{C}$ for 24 hours. Zone of inhibition was calculated in millimeter. Varying concentration of SRB extract was tested against acne causing microorganism to find the minimum inhibitory concentration (MIC). $0.020 \mathrm{ml}$ of overnight culture of bacteria at $37^{\circ} \mathrm{C}$ was added in 10 different test tube containing $10 \mathrm{ml}$ of nutrient broth. Varying concentrations of SRB extract was added to each test tube was incubated for $24 \mathrm{hr}$ and absorbance was recorded at 600nm. General antibiotic (streptomycin) was used as a control.

\subsection{In vitro anti-fungal activity of sterol rich butanolic extract}

Specific extract concentrations were prepared in sterilized water and the resulting extracts were used to evaluate their antidandruff activity by means of a disc diffusion method. On Sabouraud's agar supplemented with olive oil, dandruff sample was inoculated and incubated at $37^{\circ} \mathrm{C}$ (17). The diameter of inhibition zone according to the concentration of extract was measured in millimeters. Experiments were carried out with triplicates. The procedure was also performed for dandruff causing fungus for the standard antifungal (fucanozol) without SRB extract (standard). A plate with Sabouraud's dextrose agar was prepared as a control.

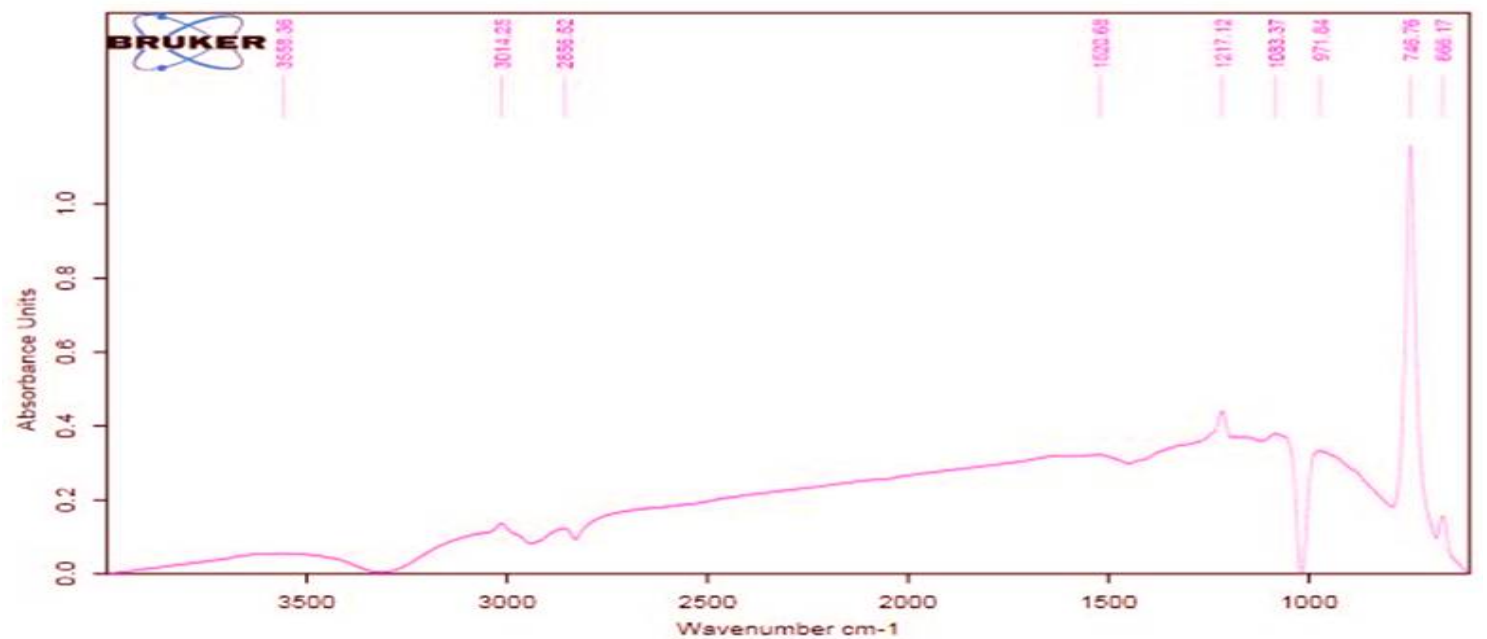

Fig. 3. FTIR peaks of SRB extract. 


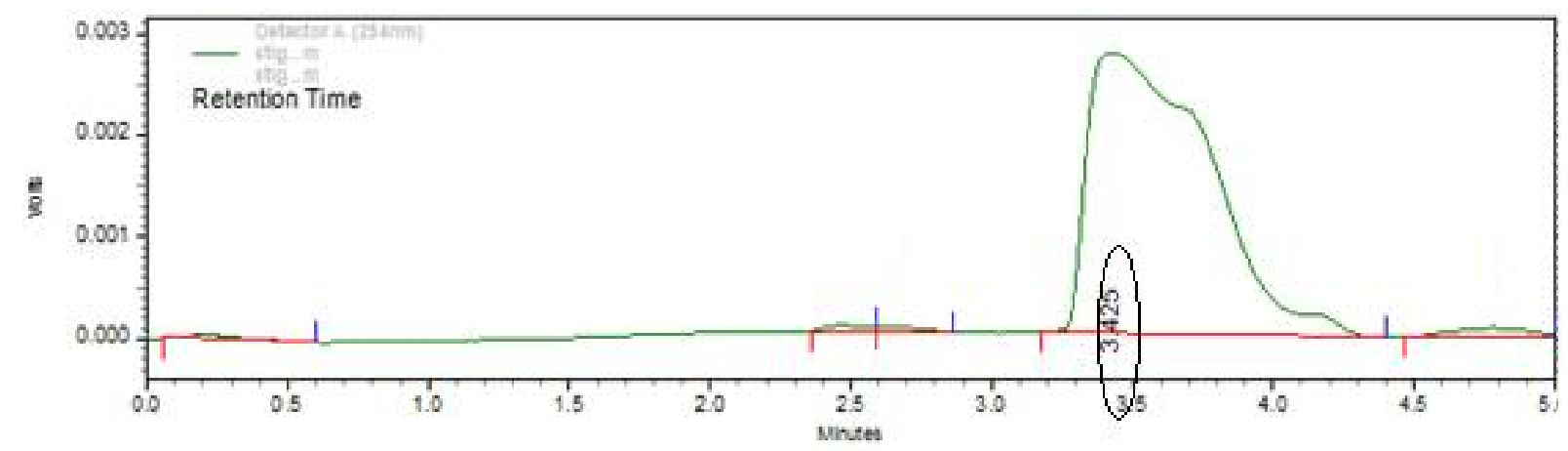

Fig. 4. (a). HPLC chromatogram of standard stigmasterol.

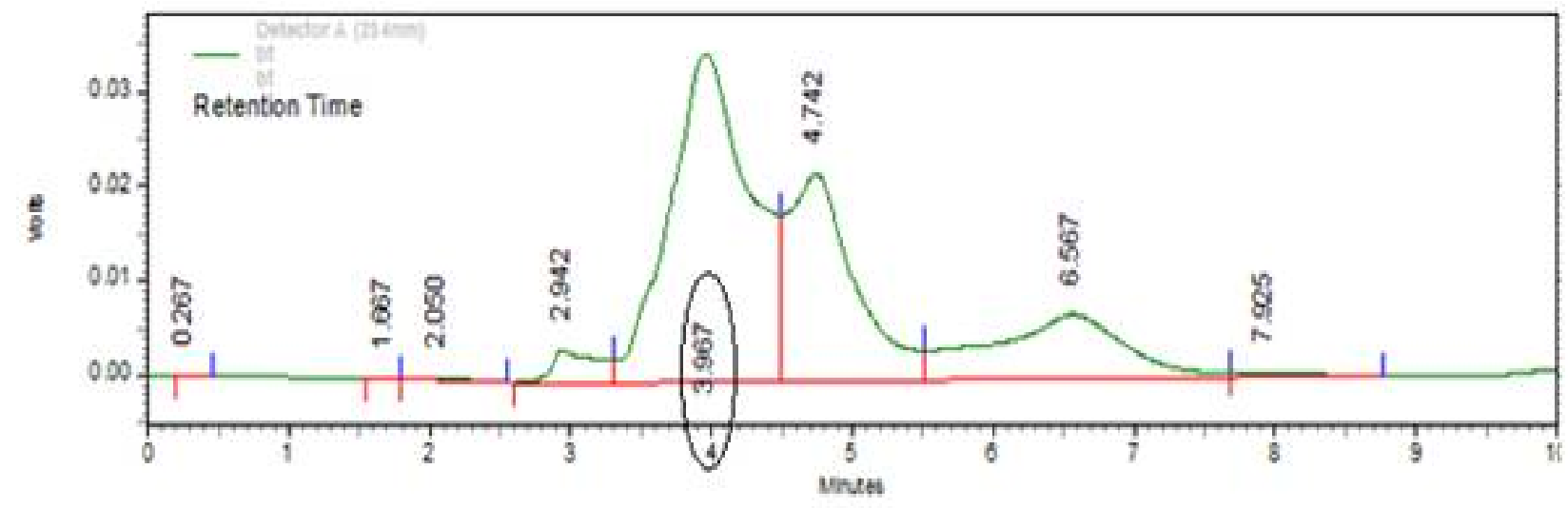

Fig. 4 (b). HPLC chromatogram of SRB extract of safflower seed waste.

\section{Results and Discussion}

\subsection{Phytochemical analysis}

The methanolic extract of SSW showed the maximum presence of saponin than ethanol, petroleum ether respectively whereas in chloroform extract it was absent. The foam test gave the confirmation of the presence of saponin (18).

The methanolic extract has shown the presence of various bioactive compounds viz. terpenoids, steroids, tannins, saponin, alkaloids, proteins, flavonoids and carbohydrates (Fig. 1).

Similarly, there are reports on the presence of compounds like glycosides, coumarins, polysaccharides, steroids and fatty acids in extracts of SSW (19).

\subsection{Characterization of sterol compounds}

The thin layer chromatography of both normal and reverse phases provides excellent qualitative data for estimating plant material saponins (20). There were various spots of SRB extract after separation present on TLC, but one spot (RF 0.67) coincided with that of standard stigmasterol $\left(\mathrm{R}_{\mathrm{f}}\right.$ $0.665)$. The spots turned violet when vanillin spray was sprayed. The values for these spots were calculated as for SRB extract and for the standard (Fig. 2).

The FTIR analysis of butanolic extract of leaf showed distinguished and characteristic peaks at $3558.35,3014.25,2856.62,1620.69,1217.12$, 1033.37, 971.84, 746.76, 666.17 corresponding to alcohols, alkanes, alkanes, alkanes, alkanes, alkenes, alkenes, alkenes, alkenes respectively (Fig. 3).

According to previous findings, similar results were obtained in aqueous methanol extract of sea grass (21).

HPLC on $\mathrm{C}_{18}$ reverse-phase column have been used for separation and identification of steroidal saponins of Digitalis purpurea, Convallaria majalis and Asparagus officinalis. Acetonitrile and methanol were used for gradient elution (22). HPLC quantification of stigmasterol as a standard, showed retention time at $3.425 \mathrm{~min}$ (Fig. 4a) while SRB extract showed retention time at 3.967 min (Fig. 4b).

The obtained peaks were the nearly same due to the presence of different sterol rich compounds. Previous studies on Bupleurum falcatum showed the presence of saikosaponin a, c and d compounds (23).

\subsection{In vitro antiacne and anti dandruff activity}

Antibiotic activity testing of SRB extract was conducted using disc diffusion against acnecausing bacteria. The zone of inhibition was measured and diameter of $11 \mathrm{~mm}$ for SRB extract, $20 \mathrm{~mm}$ for antibiotic was recorded whereas there was no inhibition of microbial growth observed in control (solvent) (Fig. 5).

Hence SRB extract showed significant antimicrobial activity against acne causing bacteria. The methanolic extract of Curcuma longa 
rhizome was tested against Staphylococcus aureus which showed satisfactory antimicrobial activity (24).

In the present study, the zone of inhibition recorded was $11 \mathrm{~mm}$ for isolated SRB and no visible zone was observed against butanol control, hence it is concluded that SRB extract is potent against acne causing bacteria.

Antidandruff activity of SRB extract was also checked by disk diffusion method. The zone of inhibition against dandruff causing microbes was measured $9 \mathrm{~mm}$ for SRB extract, $3 \mathrm{~mm}$ for Antifungal (fucanozol), and there was no zone of inhibition of solvent (control) (Fig. 6).

Table 2. MIC values of the diluted SRB extract.

\begin{tabular}{ll}
\hline Dilution of SRB Extract & MIC of SRB extract \\
\hline Standard & 0.599 \\
\hline $2 \mathrm{X}$ & 0.439 \\
\hline $4 \mathrm{X}$ & 0.387 \\
\hline $6 \mathrm{X}$ & 0.280 \\
\hline $8 \mathrm{X}$ & 0.256 \\
\hline
\end{tabular}

These results confirmed the antidandruff activity of SRB extract. Similar results were obtained from ethanolic extract of Hibiscus rosasinensis against dandruff causing Malassezia furfur (25).

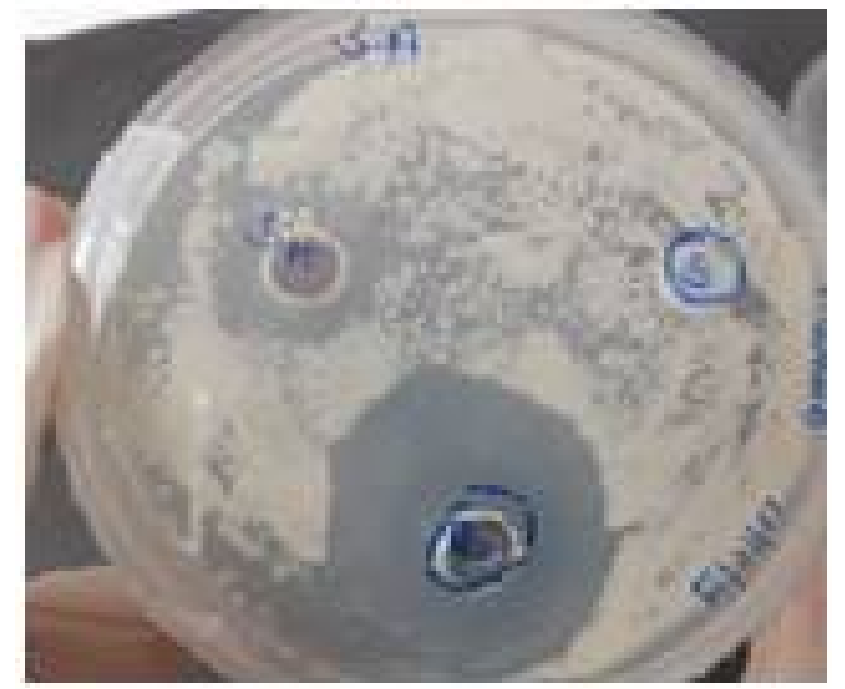

Fig. 5. Anti acne activity of SRB extracts (SR), Solvent (S), and Antibiotic streptomycin (Ab).

Antimicrobial compounds isolated from plants act as a good source of medicine because of their large therapical ability (26). Roots of Cleome ciliata Schum. \& Thonn. have a variety of bioactive compounds like terpenoids, alkaloids, tannins and saponins that posses antibacterial and antifungal properties (27). Table 2 revealed minimal inhibitory concentration (MIC) values of acnepresent micro organisms.

The highest MIC value was in 2 time's diluted extract. The lowest MIC value was found in 8 time diluted extract.

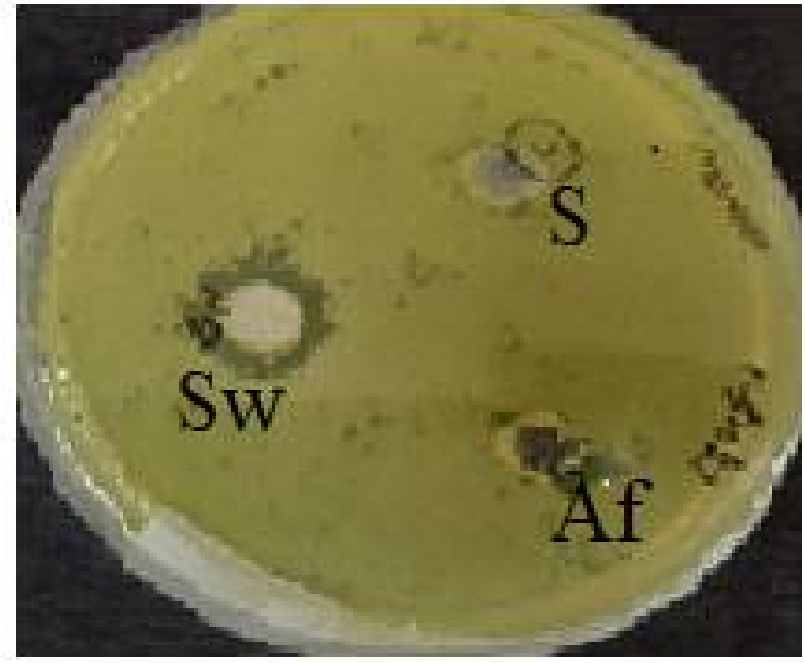

Fig. 6. Anti dandruff activity of SRB extract (Sw), solvent (S), Antifungal fucanazol (Af).

Significant results have been obtained against the dandruff in the petroleum ether extract of Tridax procumbens (28). The green tea seed extract is a high amount of saponins which showed antibacterial actions against Streptococcus aureus (ATCC 12600), Escherichia coli (ATCC 25922), and six salmonella strains (29). The form forming ability of saponin also help to destruct the cell wall of microbial cell that further cause the leakage of proteins and enzymes from that cell. The antibacterial activity of Cassia auriculata extract is possibly linked to the presence of flavonoids, steroid and saponins (30).

\section{Conclusion}

Though safflower is oil yielding rabi crop and highly rich in secondary metabolite. Its seed coat has been found rich in some antinutritional factor (saponin etc). Therefore, the current study follows to isolate and characterize the saponin compounds from the seed waste, indirectly participating in the environmental waste management. Since saponin acts to control the wide range of microbial growth, so expected saponin were tested against acne and dandruff causing microbes. In which stigma sterol has been given better response to control the growth of these microbes. The aim of the study was reutilization of these natural compounds present in waste for their maximum participation in pharma industry. In future our findings with more novel compounds present in safflower seed waste with detailed mechanism of action against acne and dandruff causing microbes may add a new step in pharma industry.

\section{Conflict of interest}

The authors declare that they have no conflict of interest.

\section{Authors' contribution}

MC has performed the experiment under the guidance of NS; NS has designed the entire 
concept, analyzed the data, edited and finalized the manuscript. VV has helped in the experimental procedures along with data compilation.

\section{Acknowledgements}

The authors are grateful to Prof. Aditya Shastri, Vice Chancellor, Banasthali Vidyapith for providing all necessary support. We acknowledge the Bioinformatics Center, Banasthali Vidyapith supported by DBT for providing computation support, and DST for providing networking and equipment support through the FIST and CURIE programs at the Department of Bioscience and Biotechnology. CESME, Banasthali Vidyapith, supported by MHRD, Government of India under the PMMMNMTT is acknowledged for organizing the symposium.

\section{References}

1. Andrews JM. Determination of minimum inhibitory concentrations. Journal of Antimicrobial Chemotherapy. 2001;48:5-16. https://doi.org/10.1093/jac/48.suppl 1.5

2. Saxena HO, Soni A, Mohammad N, Choubey SK. Phytochemical screening and elemental analysis in different plant parts of Uraria picta Desv, A Dashmul species. Journal of Chemical and Pharmaceutical Research. 2014;6:756-60. https://www.researchgate.net/publication/265849774

3. Negi JS, Negi PS, Pant GJ, Rawat MSM, Negi SK. Naturally occurring saponins: Chemistry and biology. Journal of Poisonous and Medicinal Plant Research. 2013;1:01-06. http://apexjournal.org/jpmpr/archive/2013/May/fulltext/Ne gi\%20et\%20al.pdf

4. Murugan T, Albino WJ, Murugan M. Antimicrobial Activity and Phytochemical Constituents of Leaf Extracts of Cassia auriculata. Indian Journal of Pharmacological Sciences. 2013;75:122-25. https://doi.org/10.1155/2013/621459

5. Mandal P, Sinha BSP, Mandal NC. Antimicrobial activity of saponins from Acacia auriculiformis. Fitoterapia. 2005;76:462-65. https://doi.org/10.1016/j.fitote.2005.03.004

6. Nagesh KS, Shanthamma C. Antibacterial activity of Curculigoorchioides rhizome extract on pathogenic bacteria African Journal of Microbiology Research. 2009;3:05-09. http://www.academicjournals.org/app/webroot/article/arti cle1380127779 Nagesh\%20and\%20\%20Shanthamma.pdf

7. Mandal S, Guptan P, Owusu-Ansah E, Banerjee U. Mitochondrial regulation of cell cycle progression during development as revealed by the tenured mutation revealed in Drosophila. Developmental Cell.2005;9:843-54. https://doi.org/10.1016/j.devcel.2005.11.006

8. Rowland JRJ. Dryland Farming in Africa. London and Basingstoke: Macmillan; Wageningen. Published in cooperation with Technical Centre for Agricultural and Rural Cooperation. https://cgspace.cgiar.org/handle/10568/49220

9. Heuze V, Tran G, Chapoutot P, Renaudeau D, Bastianelli D, Lebas F. Safflower (Carthamus tinctorius) seeds and oil meal. Feedipedia, a programme by INRA, CIRAD, AFZ \& FAO, 2015;10:51. https://agritrop.cirad.fr/582514/1/ID582514.pdf

10. Trease GE, Evans WS. Pharmacology, 11th edn. Bailliere Tindall Ltd, London, 1978; pp. 60-75. https://doi.org/10.4236/ $\underline{\text { ns.2014.61003 }}$

11. Wei L, Sun Y, Yan T, Yang YS, Lee JS, Byun JH, Moon CH, Han SC, Young HK. Isolation of Nematicidal Triterpenoid Saponins from Pulsatilla koreana root and their activities against. Meloidogyne incognita. Molecules. 2011;16:4438-50. https://doi.org/10.3390/molecules18055306

12. Hassan SM, Aqil AAAL, Attimarad M. Determination of crude saponin and total flavonoids content in guar meal. Advancement in Medicinal Plant Research. 2013;1:24-28. http://www.netjournals.org/z-AMPR-13-013.html

13. Narayanan B, Sakthivel N. Coriander leaf mediated biosynthesis of gold nanoparticles. Material Letters. 2008;62: 4588-90. https://www.researchgate.net/publication/222011022

14. Sasidharan S, Chen Y, Saravanan D, Sundram KM, Yoga LL. Extraction, isolation and characterization of bioactive compounds from plants' extracts. African Journal of Traditional, Complementary \& Alternative Medicines. 2011; 8:1-10. https://ncbi.nlm.nih.gov/pmc/articles/PMC3218439

15. Negi JS, Singh P., Pant GJN, Rawat MSM. High performance liquid chromatography analysis of plant saponins. Pharmacognosy. 2011;5:155-58. https://doi.org/10.4103/0973$\underline{7847.91109}$

16. Collins $\mathrm{CH}$, Lyne $\mathrm{PH}$. Microbiological methods, $8^{\text {th }}$ edn Arnold publisher, London. 1970; pp. 168-86 https://mmstcchemistry.weebly.com/uploads/2/4/1/2/24121 933/microbiological methods.pdf

17. Sibi G, Gurumeetkaur GD, Dhananjaya K, Ravikumar KR, Mallesha. Anti-dandruff activity of Ricinus communis L. leaf extracts. International Journal of Current Pharmaceutical Research. 2012;4:74-76.

18. Santhi K, Sengottuvel R. Qualitative and Quantitative Phytochemical analysis of Moringa concanensis Nimmo. International Journal of Current Microbiology and Applied Science. https://doi.org/10.20546/ijcmas.2016.501.064

2016;5:633-40

19. Zhou FR, Zhao MB, Tu PF. Simultaneous determination of four nucleosides in Carthamus tinctorius L. and Safflower injection using high performance liquid chromatography. Journal of Chinese Pharmaceutical Sciences. 2009;18:326-30.

20. Oleszek W, Bialy Z. Chromatographic determination of plant saponins-an update 2002-2005. Journal of Chromatography A. https://doi.org/10.1016/j.chroma.2006.01.037

21. Rengasamy R., Raja Kannan R., Arumugam R., Anantharaman P. Antibacterial potential of three seagrasses against human pathogens. Asian Pacific Journal of Tropical Medicine. 2010;3:890-93 https://www.researchgate.net/publication/286915540

22. Oleszek WA. Chromatographic determination of plant saponins. Journal of Chromatography A. 2002;967:147-62. https://doi.org/10.1016/s0021-9673(01)01556-4

23. In-Seon P, Eun MK, Namsoo K. High-Performance Liquid Chromatographic Analysis of Saponin Compounds in Bupleurum falcatum. Journal of Chromatographic Science. 2000;38. https://doi.org/10.1093/chromsci/38.6.229

24. Ankur G, Surabhi M, Rajendra S. Evaluation of antimicrobial activity of Curcuma longa rhizome extract against Staphylococcus aureus. Biotechnology Reports. 2015;6:51-55. https://doi.org/10.1016/j.btre.2015.02.001

25. Meena DS, Pavithra MKS. Antifungal activity by ethanolic extracts of medicinal plants against Malassezia furfur: A potential application in the treatment of Dandruff International Journal of Pharmtech Research. 2015;8:440-43. http://sphinxsai.com/2015/ph vol8 no3/3/(440-443)V8N3.pdf

26. Liu H, Crawford JH, Pierce RB, Norris P, Platnick SE, Chen G, et al. Radiative effect of clouds on tropospheric chemistry in a global three-dimensional chemical transport model Journal of Geophysical Research. 2006;111:D20303. https://doi.org/10.1029/2005JD006403

27. Innocent CO, Chinelo AE. Phytochemical screening and in vitro antimicrobial activity of various parts of Cleome ciliata Schum. \& Thonn. International Journal of Research Sstudies in Biosciences. 2019;11:2018. https://academic-oup- 
com.eres.qnl.qa/biohorizons/article/doi/10.1093/biohorizons hzy018/5304541

28. Sagar DR, Kelly S, Millns PJ, O’Shaughnessey CT, Kendall DA, Chapman V. Inhibitory effects of CB1 and CB2 receptor agonists on responses of DRG neurons and dorsal horn neurons in neuropathic rats. European Journal of Neurosciences.

$2005 ; 22: 371-79$ https://doi.org/10.1111/j.1460-9568.2005.04206.x

29. Khan MI, Ahhmed A, Shin JH, Baek JS, Kim MY, Kim JD. Green tea seed isolated saponins exerts antibacterial effects against various strains of gram positive and gram negative bacteria, a comprehensive study in vitro and in vivo. Evidence Based Complementary and Alternative Medicine. 2018;2018:12. https://doi.org/10.1155/2018/3486106

30. Murugan T, Albino JW, Murugan M. Antimicrobial activity and phytochemical constituents of leaf extracts of Cassia auriculata. Indian Journal of Pharmaceutical Sciences. 2013;75:122-25. https://doi.org/10.4103/0250-474X.113546 